\title{
The Effect of Banks Website Service Quality and E-satisfaction on E-loyalty: An Empirical Study on Swedish Banks
}

\author{
Samer Alkhouli ${ }^{1}$ \\ ${ }^{1}$ School of Business, Örebro University, Sweden \\ Correspondence: Samer Alkhouli, School of Business, Örebro University, Sweden. E-mail: \\ sameralkhouli@gmail.com \\ Received: August 7, 2017 \\ Accepted: November 13, 2017 \\ Online Published: December 20, 2017 \\ doi:10.5539/ijbm.v13n1p1 \\ URL: https://doi.org/10.5539/ijbm.v13n1p1
}

\begin{abstract}
The increase in internet use in Sweden provides the country's banking industry with an important commercial opportunity. High websites service quality (website SQ) and electronic satisfaction (e-satisfaction) are vital if the banks are to keep and guarantee their customers' electronic loyalty (e-loyalty). The purpose of this study is to provide empirical evidence of the association between website SQ and e-satisfaction, and the impact of both on e-loyalty in Swedish banks. The author used the E-S-QUAL model to measure the four dimensions of website SQ: fulfilment, availability, efficiency and privacy. Questionnaires were sent to 450 customers, of which 213 were returned, either in-person or online. The results showed that website SQ and e-satisfaction have a strong positive correlation with e-loyalty. The relationship between website SQ and e-satisfaction should be continuously measured, and website processes reviewed in line with advances in ICT and changes in levels of e-loyalty. This study gives feedback to these banks on their website SQ, helping them avoid shortcomings and keep their customers satisfied and loyal. Customers with high levels of e-satisfaction have significantly higher levels of e-loyalty compared to those with low levels.
\end{abstract}

Keywords: website services quality, e-satisfaction, e-loyalty, satisfaction, loyalty, E-S-QUAL, Swedish banks

\section{Introduction}

"The use of the Internet is becoming ever more widespread during the last two decades. This is because, on one hand, the number of products and services provided through this technological mean is growing and on the other, people are getting more and more used to interacting with it." (Paschaloudis \& Tsourela, 2015).

\subsection{Background}

Market competition has increased due to globalization and deregulation, with organizations continually increasing their productivity and decreasing their costs (Fredriksson, 2003). Information and communication technology (ICT) has changed the way services are delivered. The use of e-services has increased because they save customers time and are more convenient (Paschaloudis \& Tsourela, 2015). ICT is vital to increasing productivity and decreasing costs.

The use of ICT has rapidly increased in the banking industry, with innovations including automated teller machines (ATMs), telephone banking and website services (Saranya, Anitha, \& Vasantha, 2014). Website services has become an attractive alternative to visiting a bank in person for many customers (Kenova \& Jonasson, 2006). Reasons that customers give for preferring to use banks' website services include: convenience, feeling more in control of the process, a desire to avoid human contact and the ability to save time (Kenova \& Jonasson, 2006). The way in which customers carry out banking, and other everyday activities such as shopping, has changed over the past decade. With the increased use of ICT has come an increase in the use of web services (Fredriksson, 2003).

\subsection{Website Service Quality}

According to Lewis and Booms (1983), "Service quality is a measure of how well the service level delivered matches customer expectations. Delivering quality service means conforming to customer expectations on a consistent basis". The provision of a high-quality service is essential to success and survival in today's competitive environment (Zeithaml, Berry, \& Parasuraman, 1996). 
According to Centeno (2003), banks developed remote distribution service channels more than two decades ago. A bank's website is a channel between it and its customers, providing "moments of truth" between bank and customer (Iwaarden, der Wiele, Ball, \& Millen, 2003). Parasuraman, Zeithaml, and Malhotra (2005) describe the quality of services provided by bank websites, over all phases of interaction, as "The extent to which a Website facilitates efficient and effective shopping, purchasing, and delivery".

Provision of high quality website services is vital to companies such as Amazon, eBay, Forex Bank and COMVIQ, all of which sell products and services through their website. They are unable to reach their customers in any other way. Nearly all companies with a physical presence also use websites to sell products and reach new customers (Parasuraman et al., 2005).

\subsection{Use of Bank Website Services in Sweden}

There are four main categories of bank in Sweden: commercial banks, foreign banks, savings bank and co-operative banks. In December 2016, Sweden had a total of 117 banks. The number of commercial and foreign bank branches in Sweden increased from 48 in 2004 to 68 in 2016 (Bank- and finance statistics 2016, 2017; Banks in Sweden, 2015). According to a survey carried out by the Riksbank (Riksbank, 2016) to gain understanding of the Swedish payment habits, $85 \%$ of payments are made via banks' website . In mid-2002, Sweden had an internet banking adoption rate of 67\%, the highest in Europe (Fredriksson, 2003). In general, Swedish people enjoy easy access to the internet, with $93 \%$ of the population aged between 16 to 85 having access. Internet banking is the third-most common use of the internet for Swedish 16 to 85 year-olds ("E-commerce popular among individuals," 2016). This may be because Swedish banks are the best in the world for the provision of internet services. All major banks in Sweden offer the ability to use website services, including the ability to obtain information about accounts and assets, manage payments and buy and sell (Charif, Aronsohn, \& Charif, 2006).

\subsection{Satisfaction and E-Satisfaction}

Fredriksson (2003) says that "Customer satisfaction is a necessary condition for developing service loyalty". Customer satisfaction has been defined in various contexts by different authors. Eid (2011) defined customer satisfaction in terms of how satisfied a customer is with the service provided. Casaló, Flavián, and Guinalíu (2008) believed that satisfaction is a condition that results from assessment of all aspects of a customer's relationship with a service provider. Customer satisfaction is based on a series of purchase and consumption experiences, and is more useful and reliable as a diagnostic tool than as an examination of transactions based on a small number of purchases and consumer experiences (Marete, Gommans, \& George, 2014). According to Anderson and Srinivasan (2003) e-satisfaction is customer satisfaction with respect to electronic purchasing from internet-based companies. Banks need to consider that a greater degree of e-satisfaction leads to higher e-loyalty (Casaló et al., 2008).

\subsection{Loyalty and E-Loyalty}

Research on customer loyalty has focused mainly on product or brand loyalty, while relatively few researchers have evaluated loyalty to service organizations. In addition, "Service organizations are continually looking for ways to increase customer loyalty" (Fredriksson, 2003). Kollat, Engel, and Blackwell (1970) define brand loyalty in terms of brand choice concatenations, purchase ratio, the likelihood of a repeat purchase and brand prioritization over time. Other researchers have argued that the development of loyalty is an objective traditionally aimed for by managers, since it leads to increases in future purchasing (Casaló et al., 2008). They also argue that loyalty is a defined by a customer's intention or predisposition to purchase from the same organization again. According to Anderson and Srinivasan (2003), e-loyalty is customers behaviour toward an electronic business, leading to repeat buying behaviour.

In this study, e-loyalty is defined as the perceived loyalty of customers towards banks' e-services, their intention to use those services again and their intention to recommend them to others (Anderson \& Srinivasan, 2003). Greater customer loyalty is directly and positively correlated to high levels of website use (Casaló et al., 2008).

\section{Literature Review}

Multiple researchers have studied bank website SQ, customer satisfaction, customer loyalty and the relationship between them. Paschaloudis and Tsourela (2015) measured website SQ in Greek banks. Their study used the E-S-QUAL model to investigate the effect of e-services on customer perceptions of overall service quality. The study showed that the perceived value of a bank's website depends on fulfilment, compensation, efficiency and responsiveness. Efficient systems, available without interruption, led to maximum customer satisfaction levels in Greece. Paschaloudis and Tsourela (2015) concluded that "provision of a high level of website e-service quality 
is a goal that every bank must try to achieve".

Ariff, Yun, Zakuan, and Ismail (2013) studied the extended established relationship between bank website SQ, e-satisfaction and e-loyalty in Malaysia. Website SQ was found to have a significant impact on e-satisfaction. Improved website SQ leads to higher e-satisfaction and e-satisfaction has a significant positive effect on e-loyalty. A modified E-SERVQUAL model was used in this study.

Ting, Ariff, Zakuan, Sulaiman, and Saman (2016) measured the relationship between website SQ, e-satisfaction and e-loyalty in online shopping using the E-SERVQUAL model. They found that website SQ significantly influenced e-satisfaction and that this in turn influenced e-loyalty. This association was observed in other services, including banks and hotels. Yusuf, Javan, and Jacob (2015) studied Nigerian banks. Their study shows that to keep their customers, banks need to provide relevant, high-quality e-services. Services that meet customers' needs will gain loyalty. The quality of website services has an impact on both satisfaction and loyalty and banks design their websites with usability and usefulness in mind. Marete et al. (2014) evaluated customer satisfaction with the National Bank of Kenya. They concluded that the provision of more e-services leads to more satisfied customers.

There is a lack of studies in this field in Sweden, with only degree theses available. Charif et al. (2006), in a masters' thesis, studied e-banking in four major Swedish banks. They showed that to provide customers with good-quality e-services, banks need to put more effort into developing their e-banking, with the provision of a personalized service important to increasing customer satisfaction. Kenova and Jonasson (2006)'s thesis study looked at people living in the university area, and other areas chosen at random, in Jönköping Sweden. The study used a different version of the SERVQUAL and E-S-QUAL model. It showed that most customers are dissatisfied with or indifferent to some aspects of website services, including website design.

This study, unique in Sweden, evaluates website service quality and customer e-satisfaction and the impact on customer e-loyalty in Swedish banks.

\subsection{Aim of the Study and Research Question}

In their quest to increase customer loyalty, most banks try their best to satisfy their customers' needs and develop a long-term relationship with them. Customers loyal to a specific bank may be worth up to 10 times more than other customers. Without customer loyalty, even the best service provision will not prevent an organization from developing problems. Customer satisfaction levels are an important indicator of how likely customers are to be loyal (Anderson \& Srinivasan, 2003). Website SQ leads to e-loyalty, while e-satisfaction is a mediator of the relationship between website SQ and e-loyalty (Ariff et al., 2013).

The purpose of this research is to provide empirical evidence on the association between website SQ and e-satisfaction and their impact on e-loyalty in Swedish banks. So that the study could focus more on customers' e-loyalty, the research question used was:

"How does website SQ and customer e-satisfaction impact on customer e-loyalty in Swedish banks?"

The research objectives were: to evaluate Swedish banks' website SQ, to measure levels of e-satisfaction, and to establish the effect of e-loyalty on banks. The study will give feedback to the banks on possible shortcomings in the quality of their website services and how to avoid them. Customers will be given the opportunity to evaluate their experiences with bank websites. This research will add to the existing body of Swedish research into customer e-loyalty.

\section{Theoretical Framework}

\subsection{Previous Research}

During the past two decades, there has been extensive research into traditional SQ (non-internet-based customer interactions). Only a limited number of studies have looked at website SQ (Parasuraman et al., 2005). Parasuraman, Zeithaml, and Berry (1985) developed the SERVQUAL model to measure SQ, with the dimensions of this model being reliability, responsiveness, competence, access, and tangibles. Website SQ dimensions are different from traditional SQ in terms of human and technology interaction, website design and efficiency (Paschaloudis \& Tsourela, 2015).

Several models have been developed to measure website service quality. After review of the literature, some models of measuring website SQ were extracted, table 1 contains examples of models used to assess website SQ. Szymanski and Hise (2000) argued that satisfaction is the key to marketing. There is a lack of research into e-satisfaction, even though such research would help banks increase their levels of e-satisfaction. Szymanski and Hise (2000) have developed a model that measures e-satisfaction with these dimensions: online convenience, 
merchandising, site design, and financial security.

An e-loyalty model has been developed by (Gommans, Krishnan, \& Scheffold, 2001). They propose these dimensions for it: value propositions, brand building, trust and security, website and technology, and customer service.

Table 1. Models were used to measure website SQ

\begin{tabular}{|c|c|c|}
\hline Model & Author & Dimensions \\
\hline SITEQUAL & (Yoo \& Donthu, 2001) & Ease of use, aesthetic design, processing speed, and security \\
\hline WEBQUAL & $\begin{array}{l}\text { (Loiacono, Watson, \& Goodhue, } \\
\text { 2002) }\end{array}$ & $\begin{array}{l}\text { Ease of Use, Usefulness, Entertainment, Complementary and } \\
\text { Customer } \\
\text { Service }\end{array}$ \\
\hline E-S-QUAL & (Parasuraman et al., 2005) & $\begin{array}{l}\text { Efficiency Fulfilment, System availability, Privacy, Responsiveness, } \\
\text { Compensation and Contact }\end{array}$ \\
\hline $\begin{array}{l}\text { QoWS } \\
\text { Quality of Web } \\
\text { Service }\end{array}$ & (Guo, Gao, \& Zhang, 2008) & $\begin{array}{l}\text { Expected QoWS, Agreed QoWS, Delivered QoWS, Perceived QoWS, } \\
\text { Transmitted QoWS and Statistic QoWS }\end{array}$ \\
\hline SERVQUAL ${ }^{*}$ & (Lee \& Lin, 2005) & $\begin{array}{l}\text { Web site design, Reliability, Responsiveness, Trust, Personalization, } \\
\text { Overall service quality, Customer satisfaction and Purchase intentions }\end{array}$ \\
\hline
\end{tabular}

\subsection{Research Model}

Figure 1 illustrates the research framework, using insight gained from the existing literature as its theoretical basis.

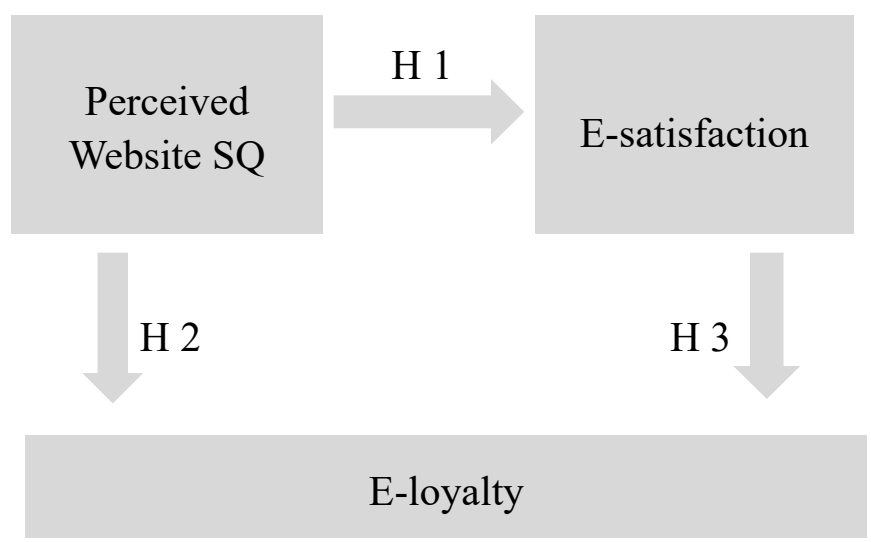

Figure 1. Research framework

The author chose to use a multiple-item model (E-S-QUAL) to measure the service quality delivered by bank websites. Parasuraman et al. (2005) developed E-S-QUAL with the sole purpose of measuring website service quality.

The E-S-QUAL model is similar to the SERVQUAL model, also developed specifically to measure website SQ (Kenova \& Jonasson, 2006). E-S-QUAL is considered an extension to SERVQUAL (Paschaloudis \& Tsourela, 2015). E-S-QUAL model was used in many studies related to website SQ, such as (Gounaris, Tanyeri, Duman Kurt, \& Atrek, 2012; Kim, Kim, \& Lennon, 2006; Rafiq, Lu, \& Fulford, 2012; Sun, Wang, \& Cao, 2009).

This model consists of two scales. The first is the basic E-S-QUAL scale with four dimensions: efficiency, fulfilment, availability, and privacy. Table 2 illustrates the dimensions and describes them. The second scale is E-RecS-QUAL, which measures only non-routine customer encounters with websites. It has three dimensions: responsiveness, compensation, and contact (Parasuraman et al., 2005). The author has not used the E-RecS-QUAL scale because: 
- The purpose of the E-RecS-QUAL scale is limited and it is therefore difficult to use it effectively. It is only relevant to a small number of customers.

- This scale does not fit the study's scope, which is to examine e-loyalty with regard to website SQ and e-satisfaction. E-RecS-QUAL relates to contact via phone or direct online contact (Parasuraman et al., 2005).

Table 2. E-S-QUAL dimensions and their description

\begin{tabular}{ll}
\hline E-S-QUAL & The ease and speed of accessing and using the site \\
\hline Efficiency & The extent to which the site's promises about order delivery and item availability are fulfilled \\
Fulfilment & The correct technical functioning of the site \\
System availability & The degree to which the site is safe and protects customer information \\
Privacy &
\end{tabular}

Source: (Parasuraman et al., 2005).

E-satisfaction and e-loyalty were measured by scales adapted from previous research by (Anderson \& Srinivasan, 2003) and (Chu, Lee, \& Chao, 2012).

\subsection{Research Hypotheses}

According to Ting et al. (2016), the provision of good website SQ promotes customer satisfaction and encourages the continued use of website services. Marete et al. (2014) argue that website SQ influences customer e-satisfaction in the banking industry and identify the factors that influence website SQ and in turn, customer e-satisfaction. Paschaloudis and Tsourela (2015) found that the provision of a high level of website SQ and the customer satisfaction that results should be a target for every bank, if they are to maximise customer loyalty. This leads us to our first hypothesis.

H1. The higher the level of website SQ, the higher the level of e-satisfaction.

Successful bank website services can be divided from the unsuccessful by looking at the level of repeated use, or loyalty. (Ting et al., 2016). E-satisfaction leads to e-loyalty, and greater levels of e-loyalty can be achieved when good quality website services are provided (Anderson \& Srinivasan, 2003). Gommans et al. (2001) argued that satisfied customers tend to be more loyal, and that website SQ is a major factor influencing e-loyalty. This leads us to our second hypothesis.

H2. The higher the level of website SQ, the higher the level of e-loyalty.

Dissatisfied customers are more likely to search for alternatives. They may choose to give their loyalty to a bank that provides a better website SQ (Anderson \& Srinivasan, 2003). E-satisfaction is assumed to be a natural antecedent to e-loyalty (Anderson \& Srinivasan, 2003). E-satisfaction mediates the relationship between website SQ and e-loyalty (Ariff et al., 2013). Ting et al. (2016) argued that customer satisfaction is a direct cause of customers' loyalty in banks' website services. This leads us to our third hypothesis.

H3. The higher the level of customer e-satisfaction, the higher the level of customer e-loyalty.

\section{Research Methodology}

\subsection{Data Collection}

The author developed a questionnaire based on his review of previous research relating to website SQ, e-satisfaction and e-loyalty. The questionnaire was in Swedish, Arabic and English. During the first week of May 2017, in Örebro city, the author contacted the participants directly and personally to explain the aims of the survey and make sure the participants were all users of bank website services. The questionnaire was also sent by email and shared on Facebook. It was designed using Google Forms and SurveyPlant.com. An explanation of the aims of the survey and a request to respondents not to participate if they were not users of bank website services were included.

Data was collected anonymously from customers in a number of Swedish cities. Tables 4 and 5 show the participants' cities and the banks they used. Of 450 questionnaires sent, 213 were returned valid. 
Table 4. List of the cities of the participated customers

\begin{tabular}{lll}
\hline City & Frequency & Percent \\
\hline Örebro & 81 & 38 \\
Stockholm & 45 & 21.1 \\
Gothenburg & 27 & 12.7 \\
Malmo & 20 & 9.4 \\
Vaxjo & 11 & 5.2 \\
Västerås & 10 & 4.7 \\
Bromma & 8 & 3.8 \\
Vanersborg & 4 & 1.9 \\
Hollviken & 3 & 1.4 \\
Llimhamn & 2 & 0.9 \\
Eskilstuna & 2 & 0.9 \\
Total & 213 & 100 \\
\hline
\end{tabular}

Table 5. List of the banks of the participated customers

\begin{tabular}{lll}
\hline Bank Name & Frequency & Percent \\
\hline Swedbank & 78 & 36.6 \\
Nordea & 48 & 22.5 \\
SEB & 46 & 21.6 \\
Handelsbanken & 20 & 9.4 \\
Länsförsäkringar & 15 & 7 \\
Sparbanken & 6 & 2.8 \\
Total & 213 & 100 \\
\hline
\end{tabular}

\subsection{Measures}

A descriptive survey was used, with 26 items in three sections, as follows:

- Section 1 asked for participants' demographic information.

- Section 2 included 13 items around website SQ dimensions (availability, efficiency, privacy and fulfilment), adapted from the work of (Parasuraman et al., 2005).

- Section 3 included 8 items around e-satisfaction and e-loyalty, adapted from the works of (Chu et al., 2012) and (Anderson \& Srinivasan, 2003).

The items were formatted to be relevant to the evaluation of bank website service quality and understandable for participants. Some items were not included because they did not fit the scope of the study.

The Likert scale, which ranges from "strongly disagree" (1) to "strongly agree" (5) was used in the survey. The data was exported for analysis from Microsoft Excel to Statistical Package for Social Science, (SPSS), version 23.

\section{Results and Analysis}

Table 6 gives a summary of the sample's demographics. $52.6 \%$ of participants were male and 47.4 were female. $54 \%$ were under 40 years old, and $47.4 \%$ were university educated. The majority of respondents were male, relatively young and well-educated. According to a study of Swedish internet users' habits and needs, conducted by (Davidsson \& Findahl, 2017), this research sample's profile is close to mirroring the profile of Swedish internet users in general. Therefore, the research sample is broadly representative of Swedish society. 
Table 6. Summary of the research sample's demographics

\begin{tabular}{llll}
\hline & & Frequency & Percent \\
\hline Gender & Male & 112 & 52.6 \\
& Female & 101 & 47.4 \\
Age & Total & 213 & 100.0 \\
& Under 18 & 22 & 10.3 \\
& $19-29$ & 48 & 22.5 \\
& $30-40$ & 45 & 21.1 \\
Education & $41-50$ & 70 & 32.9 \\
& $51-60$ & 28 & 13.1 \\
& Total & 213 & 100.0 \\
& Elementary school & 23 & 10.8 \\
& High school & 89 & 41.8 \\
& University & 101 & 47.4 \\
& Total & 213 & 100.0 \\
\hline
\end{tabular}

The reliability of the questionnaires was evaluated by assessing the consistency of the items representing each dimension of website SQ, e-satisfaction and e-loyalty, using Cronbach's alpha. Table 7 shows the Cronbach's alpha values and the mean for the questionnaire items. All the reliability estimates were greater than the suggested value of 0.70 (Nunnally, 1967).

Table 7. Reliability and dimensionality of the variables used in the study

\begin{tabular}{llll}
\hline Variable & Number of items & Cronbach's Alpha & mean \\
\hline Efficiency EFF & 5 & 0.775 & 4.075 \\
Availability AVA & 3 & 0.742 & 4.191 \\
Fulfilment FUL & 3 & 0.738 & 3.997 \\
Privacy PRI & 2 & 0.759 & 4.096 \\
e-satisfaction SAT & 4 & 0.738 & 4.189 \\
e-loyalty LOY & 4 & 0.721 & 4.080 \\
\hline
\end{tabular}

A multivariate regression model was employed to study the effect of bank website SQ and customer e-satisfaction on customer e-loyalty. Regression was used to estimate the coefficients of the linear equation, involving one or more independent variables, which best predicted the value of the dependent variable (Nunnally, 1967).

H1 posits that website SQ is positively correlated with customer e-satisfaction. Table 8 shows the ANOVA test findings. The significance value is 0.000 , less than 0.05 and therefore the model is statistically significant in predicting how website SQ can affect customer e-satisfaction.

Table 8. The significant value for website SQ and e-satisfaction model. ANOVA ${ }^{\mathrm{a}}$

\begin{tabular}{llllll}
\hline & Sum of Squares & df & Mean Square & F & Sig. \\
\hline Regression & 24.799 & 4 & 6.200 & 28.013 & $.000^{\text {b }}$ \\
Residual & 46.033 & 208 & .221 & & \\
Total & 70.832 & 212 & & & \\
\hline
\end{tabular}

a. Dependent Variable: SAT.

b. Predictors: (Constant), AVA, PRI, EFF, FUL.

Four dimensions of perceived website SQ were studied: fulfilment, availability, efficiency and privacy. A multiple regression analysis was carried out to test the relationship between website SQ and customer e-satisfaction. As illustrated in Table 9, the multiple regression analysis verified that website SQ is positively and 
significantly correlated with customer e-satisfaction: $\mathrm{P}<0.05$, tolerance $>0.1$ and $\mathrm{VIF}<3$ for all variables (Nunnally, 1967). To test the hypothesis, the following regression model was run:

$$
Y=\alpha+\beta_{1} X_{1}+\beta_{2} X_{2}+\beta_{3} X_{3}+\beta_{4} X_{4}+\varepsilon
$$

Where:

$Y=$ customer e-satisfaction, $\alpha=$ constant term, $\beta_{1}, \beta_{2}, \beta_{3}, \beta_{4}=$ beta coefficients, $X_{1}=$ Fulfilment, $X_{2}=$ Availability, $\mathrm{X}_{3}=$ Efficiency, $\mathrm{X}_{4}=$ Privacy, $\varepsilon=$ error term.

Table 9. Regression result between website SQ and e-satisfaction

\begin{tabular}{|c|c|c|c|c|c|c|c|}
\hline & \multicolumn{4}{|c|}{ Unstandardized Coefficients $\begin{array}{c}\text { Standardized } \\
\text { Coefficients }\end{array}$} & \multicolumn{3}{|c|}{ Collinearity Statistics } \\
\hline & B & Std. Error & Beta & $\mathrm{t}$ & Sig. & Tolerance & VIF \\
\hline (Constant) & 1.613 & .248 & & 10.070 & .000 & & \\
\hline EFF & .415 & .060 & .428 & 6.885 & .000 & .690 & 1.450 \\
\hline AVA & .293 & .076 & .256 & 3.842 & .000 & .672 & 1.489 \\
\hline FUL & .435 & .052 & .498 & 8.337 & .000 & .521 & 1.919 \\
\hline PRI & .432 & .052 & .493 & 8.236 & .000 & .631 & 1.586 \\
\hline
\end{tabular}

Dependent Variable: SAT.

$\mathrm{H} 2$ posits that website SQ is positively correlated with customer e-loyalty. As illustrated in Table 10, the ANOVA test gives the significance value as 0.000 , which is less than 0.05 and therefore the model is statistically significant in predicting how website SQ affects customer e-loyalty.

Table 10. The significant value for website SQ and e-loyalty model ANOVA ${ }^{\mathrm{a}}$

\begin{tabular}{lllll}
\hline Sum of Squares & & df & Mean Square & F \\
\hline Regression & 28.101 & 4 & 7.025 & 32.624 \\
Residual & 44.792 & 208 & .215 & $.000^{\mathrm{b}}$ \\
Total & 72.893 & 212 & & \\
\hline
\end{tabular}

a. Dependent Variable: LOY.

b. Predictors: (Constant), FUL, EFF, AVA, PRI.

Four dimensions of perceived website SQ were studied: fulfilment, availability, efficiency and privacy. A multiple regression analysis was carried out to test this relationship. Table 11 shows that the multiple regression analysis verified that website SQ is positively and significantly correlated with customer e-loyalty: $\mathrm{P}<0.05$, tolerance $>0.1$ and VIF $<3$ for all variables (Nunnally, 1967). To test the hypothesis, the following regression model was run:

$$
Y=\alpha+\beta_{1} X_{1}+\beta_{2} X_{2}+\beta_{3} X_{3}+\beta_{4} X_{4}+\varepsilon
$$

Where:

$\mathrm{Y}=$ customer e-loyalty, $\alpha=$ constant term, $\beta_{1}, \beta_{2}, \beta_{3}, \beta_{4}=$ beta coefficients, $X_{1}=$ Fulfilment, $X_{2}=$ Availability, $X_{3}=$ Efficiency, $\mathrm{X}_{4}=$ Privacy, $\varepsilon=$ error term

\begin{tabular}{|c|c|c|c|c|c|c|c|}
\hline & \multicolumn{2}{|c|}{ Unstandardized Coefficients } & \multicolumn{2}{|l|}{ Standardized Coefficients } & \multicolumn{3}{|c|}{ Collinearity Statistics } \\
\hline & $\mathrm{B}$ & Std. Error & Beta & $\mathrm{t}$ & Sig. & Tolerance & VIF \\
\hline (Constant) & 1.302 & .308 & & 9.160 & .000 & & \\
\hline $\mathrm{EFF}$ & .442 & .060 & .450 & 7.316 & .000 & .690 & 1.450 \\
\hline AVA & .312 & .077 & .268 & 4.046 & .000 & .672 & 1.489 \\
\hline FUL & .449 & .053 & .507 & 8.545 & .000 & .521 & 1.191 \\
\hline PRI & .471 & .052 & .530 & 9.085 & .000 & .631 & 1.586 \\
\hline
\end{tabular}

Table 11. Regression result between website SQ and e-loyalty

Dependent Variable: LOY 
H3 posits that customer e-satisfaction is positively correlated with customer e-loyalty. Table 12 shows the ANOVA test findings. The significance value is 0.000 , which is less than 0.05 and therefore the model is statistically significant in predicting how customer e-satisfaction affects customer e-loyalty.

Table 12. The significant value for e-satisfaction and e-loyalty model. ANOVA ${ }^{\mathrm{a}}$

\begin{tabular}{lllll}
\hline Sum of Squares & & df & Mean Square & F \\
\hline Regression & 18.590 & 1 & 18.590 & 72.235 \\
Residual & 54.303 & 211 & .257 & $.000^{\mathrm{b}}$ \\
Total & 72.893 & 212 & & \\
\hline
\end{tabular}

a. Dependent Variable: LOY.

b. Predictors: (Constant), SAT.

Table 13 shows that multiple regression analysis verified that customer e-satisfaction is positively and significantly associated with customer e-loyalty: $\mathrm{P}<0.05$, tolerance $>0.1$ and VIF $<3$ (Nunnally, 1967). To test the hypothesis, the following regression model was run:

$$
Y=\alpha+\beta_{1} X_{I}+\varepsilon
$$

Where:

$\mathrm{Y}=$ customer e-loyalty, $\alpha=$ constant term, $\beta_{1}=$ beta coefficients, $\mathrm{X}_{1}=$ e-satisfaction, $\varepsilon=$ error term

Table 13. Regression result between e-satisfaction and e-loyalty

\begin{tabular}{lllllll}
\hline & \multicolumn{1}{c}{ Unstandardized Coefficients } & Standardized Coefficients & & \multicolumn{2}{c}{ Collinearity Statistics } \\
\hline & B & Std. Error & Beta & t & Sig. & Tolerance \\
(Constant) & 1.934 & .255 & & 7.587 & .000 & VIF \\
SAT & .512 & .060 & .505 & 8.499 & .000 & 1.000 \\
Dependent Variable: LOY & & & & & & \\
\hline
\end{tabular}

\section{Discussions}

The aim of this study was to measure the website service quality provided by Swedish banks, the resulting customer e-satisfaction and its effect on customer e-loyalty. The author proposed that website SQ and e-satisfaction determine the e-loyalty of bank customers. Our findings confirm that website SQ and e-satisfaction do predict e-loyalty.

The regression analysis indicates that the four website SQ dimensions used in this study have a positive and significant impact on e-satisfaction. This highlights that the dimensions of E-S-QUAL, fulfilment, availability, efficiency and privacy (Parasuraman et al., 2005), are strongly linked to customer e-satisfaction. This is in line with the work of (Ariff et al., 2013) and (Ting et al., 2016). Specifically, the efficiency ( $\beta$.428, Sig 0.000), availability ( $\beta .256$, Sib 0.000), fulfilment ( $\beta .498$, Sig 0.000), and privacy ( $\beta .493$, Sig 0.000$)$ of website SQ affect the e-satisfaction levels of bank customers.

The study proves that website SQ has a positive and significant impact on e-loyalty. This highlights that the dimensions of E-S-QUAL, fulfilment, availability, efficiency and privacy, (Parasuraman et al., 2005) are key features of customer e-loyalty, efficiency ( $\beta .450$, Sig 0.000$)$, availability $(\beta .268$, Sig 0.000$)$, fulfilment ( $\beta .507$, Sig 0.000$)$, and privacy $(\beta .530$, Sig 0.000$)$. This relationship is consistent with the previous literature, which shows a strong link between these two constructs (Yusuf et al., 2015) and (Chu et al., 2012).

The findings demonstrate that e-satisfaction and e-loyalty are positively linked for bank website services users ( $\beta .505$, Sig 0.000). This is consistent with previous research findings that prove that higher levels of customer e-satisfaction lead to greater customer e-loyalty (Anderson \& Srinivasan, 2003; Eid, 2011).

This study provides a number of theoretical and practical contributions to the literature on Swedish banking. The findings answer the research question and achieve its objectives, and support all three hypotheses. This study's 
contribution to academia is that it confirms that the four website SQ dimensions are important to customer e-satisfaction and e-loyalty. It also shows that website SQ and e-satisfaction are key factors influencing the e-loyalty of bank customers in Sweden. The model as presented and tested demonstrates cultural diversity and is a reasonable starting point for future investigations. The research shows that the provision of a high level of website SQ is should be an aim for every bank, in order to achieve customer e-satisfaction and gain e-loyalty. These findings are in contrast with results of some other research, including (Ariff et al., 2013; Chu et al., 2012; Paschaloudis \& Tsourela, 2015).

Finally, the author suggests that the relationship between website SQ and e-satisfaction should be continuously measured, and website processes reviewed in line with advances in ICT and changes in levels of e-loyalty.

\section{Conclusion}

This study answers the research question on effect of bank website SQ and e-satisfaction on customer e-loyalty, and supports all three research hypotheses. It proves that the provision of high quality bank website services is key to customer e-satisfaction and e-loyalty. Our findings are consistent with previous studies, such as (Ariff et al., 2013) and (Ting et al., 2016), which have shown that website service quality and customer e-satisfaction are have a positive and significant effect on customer e-loyalty. The author used the E-S-QUAL model (Parasuraman et al., 2005) to examine the four dimensions of website SQ: fulfilment, availability, efficiency and privacy, from a survey of 213 Swedish bank customers. The author conclude that the four dimensions have a positive and significant effect on customer e-satisfaction and e-loyalty. Finally, this study concludes that when banks provide high quality website services, their customers will be satisfied and e-loyalty levels will increase.

\section{Limitations and Future Research Directions}

This study focused on banks' website service quality to achieve the research objectives, in spite of there are many other services the customers used in there banks' daily transactions, such as mobile apps, swish, mobile ID. In addition the author used E-S-QUAL scale in the study and had dropped E-RecS-QUAL scale for the reasons were mentioned earlier. Finally, two variables were used to measure e-loyalty, which are website SQ and e-satisfaction.

The study recommends that further research follows those suggestions and recommendations:

- Although website services are widely used among banks customers, it is important that future studies add some more services such as swish and mobile apps.

- The study sample needs to be more big, in order to allow to use E-S-QUAL model with its both scales.

\section{References}

Anderson, R. E., \& Srinivasan, S. S. (2003). E-satisfaction and e-loyalty: A contingency framework. Psychology \& marketing, 20(2), 123-138. https://doi.org/10.1002/mar.10063

Ariff, M. S. M., Yun, L. O., Zakuan, N., \& Ismail, K. (2013). The impacts of service quality and customer satisfaction on customer loyalty in internet banking. Procedia-Social and Behavioral Sciences, 81, 469-473. https://doi.org/10.1016/j.sbspro.2013.06.462

Bank- and finance statistics 2016. (2017). Retrieved from Sweden: http://www.swedishbankers.se/media/3265/1705_bank-and-finance-statistics.pdf

Banks in Sweden. (2015). Retrieved from Sweden: http://www.swedishbankers.se/media/2669/1503-banks-in-sweden.pdf

Casaló, L. V., Flavián, C., \& Guinalíu, M. (2008). The role of satisfaction and website usability in developing customer loyalty and positive word-of-mouth in the e-banking services. International Journal of Bank Marketing, 26(6), 399-417. https://doi.org/10.1108/02652320810902433

Centeno, C. (2003). Adoption of Internet services in the enlarged European Union. European Commission Research Center.

Charif, L., Aronsohn, M., \& Charif, H. (2006). E-banking and Service Quality Online (Master Thises), Lund University.

Chu, P. Y., Lee, G. Y., \& Chao, Y. (2012). Service quality, customer satisfaction, customer trust, and loyalty in an e-banking context. Social Behavior and Personality: an international journal, 40(8), 1271-1283. https://doi.org/10.2224/sbp.2012.40.8.1271 
Davidsson, P., \& Findahl, O. (2017). Svenskarna och internet 2016. Undersökning om svenskarnas internetvanor: Internetstiftelsen i Sverige. Hämtad den.

E-commerce popular among individuals. $\quad$ (2016). Retrieved from http://www.scb.se/en/finding-statistics/statistics-by-subject-area/living-conditions/living-conditions/ict-usag e-in-households/pong/statistical-news/ict-usage-by-individuals-2016/

Eid, M. I. (2011). Determinants of e-commerce customer satisfaction, trust, and loyalty in Saudi Arabia. Journal of electronic commerce research, 12(1), 78.

Fredriksson, O. (2003). Internet-Based Self-Services: Relational Aspects of E-Banking-a Private Client Survey Analysis. Institute for Management of Innovation and Technology, Working Paper Series, 136.

Gommans, M., Krishnan, K. S., \& Scheffold, K. B. (2001). From brand loyalty to e-loyalty: A conceptual framework. Journal of Economic and Social research, 3(1), 43-58.

Gounaris, S., Tanyeri, M., Duman Kurt, S., \& Atrek, B. (2012). The classification and importance of ES-Qual quality attributes: An evaluation of online shoppers. Managing Service Quality: An International Journal, 22(6), 622-637. https://doi.org/10.1108/09604521211287589

Guo, N., Gao, T., \& Zhang, B. (2008). Trusted Assessment of Web Services Based on a Six-Dimensional QoS Model. Paper presented at the Asia-Pacific Services Computing Conference, 2008. APSCC'08. IEEE. https://doi.org/10.1109/APSCC.2008.239

Iwaarden, J., der Wiele, T., Ball, L., \& Millen, R. (2003). Applying SERVQUAL to web sites: An exploratory study. International Journal of Quality \& Reliability Management, 20(8), 919-935. https://doi.org/10.1108/02656710310493634

Kenova, V., \& Jonasson, P. (2006). Quality online banking services. (Bachelor Thises), JÖNKÖPING UNIVERSITY.

Kim, M., Kim, J. H., \& Lennon, S. J. (2006). Online service attributes available on apparel retail web sites: an ES-QUAL approach. Managing Service Quality: An International Journal, 16(1), 51-77. https://doi.org/10.1108/09604520610639964

Kollat, D. T., Engel, J. F., \& Blackwell, R. D. (1970). Current problems in consumer behavior research. Journal of Marketing Research, 327-332. https://doi.org/10.2307/3150290

Lee, G.-G., \& Lin, H.-F. (2005). Customer perceptions of e-service quality in online shopping. International Journal of Retail \& Distribution Management, $33(2), \quad$ 161-176. https://doi.org/10.1108/09590550510581485

Lewis, R. C., \& Booms, B. H. (1983). The marketing aspects of service quality. Emerging perspectives on services marketing, 65(4), 99-107.

Loiacono, E. T., Watson, R. T., \& Goodhue, D. L. (2002). WebQual: A measure of website quality. Marketing theory and applications, 13(3), 432-438.

Marete, J. M., Gommans, H. P., \& George, G. E. (2014). Evaluation of E-Banking Services on Customer Satisfaction: Case of National Bank of Kenya. European Journal of Business and Management, 6(22), 54-67.

Nunnally, J. C. (1967). Psychometric theory.

Parasuraman, Zeithaml, V. A., \& Berry, L. L. (1985). A conceptual model of service quality and its implications for future research. The Journal of Marketing, 41-50. https://doi.org/10.2307/1251430

Parasuraman, Zeithaml, V. A., \& Malhotra, A. (2005). ES-QUAL a multiple-item scale for assessing electronic service quality. Journal of service research, 7(3), 213-233. https://doi.org/10.1177/1094670504271156

Paschaloudis, D., \& Tsourela, M. (2015). Using ES-QUAL to Measure Internet Service Quality of EBanking Web Sites in Greece. The Journal of Internet Banking and Commerce, 2014.

Rafiq, M., Lu, X., \& Fulford, H. (2012). Measuring Internet retail service quality using ES-QUAL. Journal of Marketing Management, 28(9-10), 1159-1173. https://doi.org/10.1080/0267257X.2011.621441

Riksbank. (2016). Retrieved from http://www.riksbank.se/en/Statistics/Payment-statistics/

Saranya, J., Anitha, K., \& Vasantha, S. (2014). An Empirical Study on Role of ICT in Banking Sector. International Journal of Multidisciplinary and Current Research, 2. 
Sun, Q., Wang, C., \& Cao, H. (2009). Applying ES-QUAL scale to analysis the factors affecting consumers to use internet banking services. Paper presented at the Services Science, Management and Engineering, 2009. SSME'09. IITA International Conference on.

Szymanski, D. M., \& Hise, R. T. (2000). E-satisfaction: an initial examination. Journal of retailing, 76(3), 309-322. https://doi.org/10.1016/S0022-4359(00)00035-X

Ting, O. S., Ariff, M. S. M., Zakuan, N., Sulaiman, Z., \& Saman, M. Z. M. (2016). E-Service Quality, E-Satisfaction and E-Loyalty of Online Shoppers in Business to Consumer Market; Evidence form Malaysia. Paper presented at the IOP Conference Series: Materials Science and Engineering. https://doi.org/10.1088/1757-899X/131/1/012012

Yoo, B., \& Donthu, N. (2001). Developing a scale to measure the perceived quality of an Internet shopping site (SITEQUAL). Quarterly journal of electronic commerce, 2(1), 31-45.

Yusuf, E. E., Javan, H., \& Jacob, T. Y. (2015). An Assessment of Customers Readiness, Loyalty and Satisfaction on E-Banking Services: A Nigerian Perspective.

Zeithaml, V. A., Berry, L. L., \& Parasuraman, A. (1996). The behavioral consequences of service quality. the Journal of Marketing, 31-46. https://doi.org/10.2307/1251929

\section{Copyrights}

Copyright for this article is retained by the author(s), with first publication rights granted to the journal.

This is an open-access article distributed under the terms and conditions of the Creative Commons Attribution license (http://creativecommons.org/licenses/by/4.0/). 